Article

\title{
Antimicrobial Activity of Monoramnholipids Produced by Bacterial Strains Isolated from the Ross Sea (Antarctica) ${ }^{\dagger}$
}

\author{
Pietro Tedesco ${ }^{1}$, Isabel Maida ${ }^{2}$, Fortunato Palma Esposito ${ }^{1}$, Emiliana Tortorella ${ }^{1}$, \\ Karolina Subko ${ }^{3}$, Chidinma Christiana Ezeofor ${ }^{3}$, Ying Zhang ${ }^{3}$, Jioji Tabudravu ${ }^{3}$, \\ Marcel Jaspars ${ }^{3}$, Renato Fani ${ }^{2}$ and Donatella de Pascale ${ }^{1, *}$ \\ 1 Institute of Protein Biochemistry, National Research Council, Via P. Castellino, 111, I-80131 Naples, Italy; \\ p.tedesco@ibp.cnr.it (P.T.); f.palma@ibp.cnr.it (F.P.E.); e.tortorella@ibp.cnr.it (E.T.) \\ 2 Department of Biology, University of Florence, Via Madonna del Piano 6, I-50019 Sesto Fiorentino (FI), Italy; \\ isabel.maida@unifi.it (I.M.); renato.fani@unifi.it (R.F.) \\ 3 Marine Biodiscovery Centre, Department of Chemistry, University of Aberdeen, Old Aberdeen, AB24 3UE \\ Scotland, UK; k.subko.11@aberdeen.ac.uk (K.S.); chidinma.christiana.ezeofor.14@aberdeen.ac.uk (C.C.E.); \\ ying.zhang.14@aberdeen.ac.uk (Y.Z.); j.tabudravu@abdn.ac.uk (J.T.); m.jaspars@abdn.ac.uk (M.J.) \\ * Correspondence: d.depascale@ibp.cnr.it; Tel.: +39-081-613-2314; Fax: +39-081-613-2277 \\ + All the authors belong to the EU-FP7 PharmaSea project.
}

Academic Editor: Orazio Taglialatela-Scafati

Received: 12 December 2015; Accepted: 18 April 2016; Published: 26 April 2016

\begin{abstract}
Microorganisms living in extreme environments represent a huge reservoir of novel antimicrobial compounds and possibly of novel chemical families. Antarctica is one of the most extraordinary places on Earth and exhibits many distinctive features. Antarctic microorganisms are well known producers of valuable secondary metabolites. Specifically, several Antarctic strains have been reported to inhibit opportunistic human pathogens strains belonging to Burkholderia cepacia complex (Bcc). Herein, we applied a biodiscovery pipeline for the identification of anti-Bcc compounds. Antarctic sub-sea sediments were collected from the Ross Sea, and used to isolate 25 microorganisms, which were phylogenetically affiliated to three bacterial genera (Psychrobacter, Arthrobacter, and Pseudomonas) via sequencing and analysis of $16 \mathrm{~S}$ rRNA genes. They were then subjected to a primary cell-based screening to determine their bioactivity against Bcc strains. Positive isolates were used to produce crude extracts from microbial spent culture media, to perform the secondary screening. Strain Pseudomonas BNT1 was then selected for bioassay-guided purification employing SPE and HPLC. Finally, LC-MS and NMR structurally resolved the purified bioactive compounds. With this strategy, we achieved the isolation of three rhamnolipids, two of which were new, endowed with high (MIC $<1 \mu \mathrm{g} / \mathrm{mL}$ ) and unreported antimicrobial activity against Bcc strains.
\end{abstract}

Keywords: antimicrobials; ramnholipids; Antarctic; Bcc; microorganisms

\section{Introduction}

The alarming rise of Multi-Drug Resistance (MDR) bacteria in the last few decades has highlighted the need for novel antimicrobial compounds and for effective drug discovery approaches [1,2]. Natural products are the largest source of new antibiotic molecules, representing about two-thirds of new antibacterial therapies approved between 1980 and 2010 [3,4]. Bioprospecting for natural products from unexplored natural environments, such as the marine environment is considered a promising strategy to identify novel compounds. It is increasingly recognized that a huge number of natural products and novel chemical entities exist in these environments, but the overwhelming biological diversity of these environments has so far only been explored to a very limited extent [5,6]. The Antarctic environment, 
as well as having incredibly low temperatures, possesses other diverse traits that may have helped to shape the unique way in which Antarctic bacteria have evolved. This extreme environment contains hyper-salinity that exists in sea ice brine channels, a lack of free water due to freezing temperatures, as well as low nutrient availability. Unique light conditions also exist due to the high latitude of the region. Several studies have shown that Antarctic bacteria harvested from Antarctic corals and sponges are a promising source of new antimicrobial compounds [7-14]. Specifically, several Antarctic strains belonging to the genus Pseudoalteromonas, Psychrobacter, Pseudomonas, and Arthrobacter, were able to inhibit the growth of several strains belonging to the Burkholderia cepacia complex (Bcc) [11,14]. Further studies demonstrated that the antimicrobial activity relies (at least in part) on the production of Volatile Organic Compounds (VOCs) $[12,13,15]$. The Bcc consists of at least 20 closely related species inhabiting different ecological niches such as water, soil, plants rizosphere, and plants and animals [16-18]. Bcc are also opportunistic human pathogens that cause lung infections in immune-compromised individuals, including cystic fibrosis (CF) patients [19]. In one-third of infected individuals, it causes the "cepacia syndrome" - a form of septic shock, which involves the lungs essentially shutting down, resulting in fatality [20-22]. Bcc bacteria have proven to be very resilient and incredibly difficult to combat as they are resistant to almost all known antimicrobial agents and can survive under the most extreme conditions [23]. In this publication, we report a complete biodiscovery pipeline aiming at the identification of novel anti-Bcc compounds, starting from the isolation of bacteria from Antarctic sub-sea sediments. Bacteria were tested for their antimicrobial potential and a bioassay-guided purification was performed that yielded three bioactive compounds active against Bcc. Structures were then elucidated and two compounds have not been reported previously.

\section{Results and Discussion}

\subsection{Isolation of Bacteria, Typing and Phylogenetic Analysis}

Psychrophilic Antarctic bacteria were isolated from sediments on PYG minimal medium. After 15 days of incubation at $4{ }^{\circ} \mathrm{C}, 25$ visible colonies where picked and grown in liquid PYG at $15^{\circ} \mathrm{C}$ for $48 \mathrm{~h}$ in agitation, and glycerol stab were stored at $-80^{\circ} \mathrm{C}$.

In order to check whether the 25 bacterial isolates represented either the same or different strains, an RAPD analysis was carried out using the primers 1253 (5'-GTTTCCGCCC-3') and AP5 (5'-TCACGCTGCG-3'). The RAPD profiles obtained were then compared among them; the comparative analysis obtained with primer 1253 revealed that the 25 Antarctic isolates were split into 18 different RAPD groups (hereinafter, RAPD haplotypes), most of which were represented by just one bacterial isolate as summarized in Table 1. Two groups embedding more than one isolate were identified: group 1 (RAPD halpotype 1) including strains BTN1, BTN6, BTN 7, BTN8, BTN9 and BTN10 and group 4 (embedding isolates BTN20A, BTN20B, and BTN24). These data were completely confirmed by the RAPD analysis performed with primer AP5.

The phylogenetic affiliation of bacterial isolates was performed through the 16S rRNA genes amplification and analysis. For this purpose, the 16S rRNA genes were PCR amplified and the nucleotide sequence of the amplicons determined. Each sequence was used as a query in a BLAST search to retrieve the most similar ones. Sequences were then aligned using the program ClustalW and the alignment was used to construct the phylogenetic trees shown in Figure S1, revealing that:

(i) As expected on the basis of the sharing of RAPD profiles, the six strains exhibiting the same RAPD profile (RAPD haplotype 1) share the same 16S rRNA gene sequence and were clustered together joining the species Pseudomonas azotoformans.

(ii) Strain BTN4 was affiliated to the genus Arthrobacter.

(iii) All the other strains were affiliated to the genus Psychrobacter and, according to the different RAPD profiles they exhibited, joined different Psychrobacter clades. The three strains (BTN20A, BTN24 and BTN 20B) sharing the same RAPD profile (RAPD haplotype 4), joined the same Psychrobacter cluster. 
Table 1. List of the strains used in this work; for each strain, the genus and the RAPD haplotype are reported.

\begin{tabular}{|c|c|c|c|}
\hline Genus & Strains & RAPD Profile & Accession Number \\
\hline \multirow{6}{*}{ Pseudomonas } & BTN1 & \multirow{6}{*}{1} & KT989002 \\
\hline & BTN6 & & KT989003 \\
\hline & BTN7 & & KT989004 \\
\hline & BTN8 & & КT989005 \\
\hline & BTN9 & & KT989006 \\
\hline & BTN10 & & KT989007 \\
\hline \multirow{18}{*}{ Psychrobacter } & BTN3 & 2 & KT989009 \\
\hline & BTN19 & 3 & КT989019 \\
\hline & BTN20B & \multirow[b]{2}{*}{4} & KT989021 \\
\hline & BTN24 & & KT989022 \\
\hline & BTN21 & 5 & KT989025 \\
\hline & BTN23 & 6 & KT989024 \\
\hline & BTN2 & 7 & KT989008 \\
\hline & BTN11 & 8 & KT989011 \\
\hline & BTN5 & 9 & КT989010 \\
\hline & BTN20A & 4 & KT989020 \\
\hline & BTN15 & 10 & КT989015 \\
\hline & BTN13 & 11 & KT989012 \\
\hline & BTN14 & 12 & KT989013 \\
\hline & BTN17 & 13 & KT989017 \\
\hline & BTN16 & 14 & KT989016 \\
\hline & BTN18 & 15 & KT989018 \\
\hline & BTN12 & 16 & KT989014 \\
\hline & BTN22 & 17 & KT989023 \\
\hline Arthrobacter & BTN4 & 18 & KT989001 \\
\hline
\end{tabular}

\subsection{Cross-Streaking Experiments}

In order to check the ability of Antarctic bacteria to inhibit the growth of Bcc strains, cross-streaking experiments were performed using representatives of each RAPD haplotype as test strains. We used as targets a panel of 84 different Bcc strains belonging to 17 known species (see Table S1). Most of the strains had a clinical origin. Data obtained are summarized in Table S1, revealing that all BTN strains are able to completely inhibit the growth of Bcc strains. In order to check whether this anti-Bcc activity was due to Volatile Organic Compounds (VOCs) synthesis, a further cross-streaking experiment was performed using Petri dishes with a central septum, which physically separates the tester (Antarctic) from the target strains. To perform this analysis, we selected the $17 \mathrm{Bcc}$ type strains listed in Table S2, which are highlighted in red. Data obtained are reported in Table 2 and revealed that the inhibitory power of the BTN strains decreased in the presence of the central septum. This finding suggested that BTN strains synthesize a combination of volatile and soluble molecules and that the Bcc-inhibitory activity likely might rely principally on the soluble fraction. Thus, we decided to concentrate our efforts on the soluble molecules for this study. 
Table 2. Growth of Bcc strains in cross-streaking experiments carried out using Petri dishes either with (W) or without (N) a central septum (S). Symbols:,+ growth; \pm , reduced growth; -, no growth.

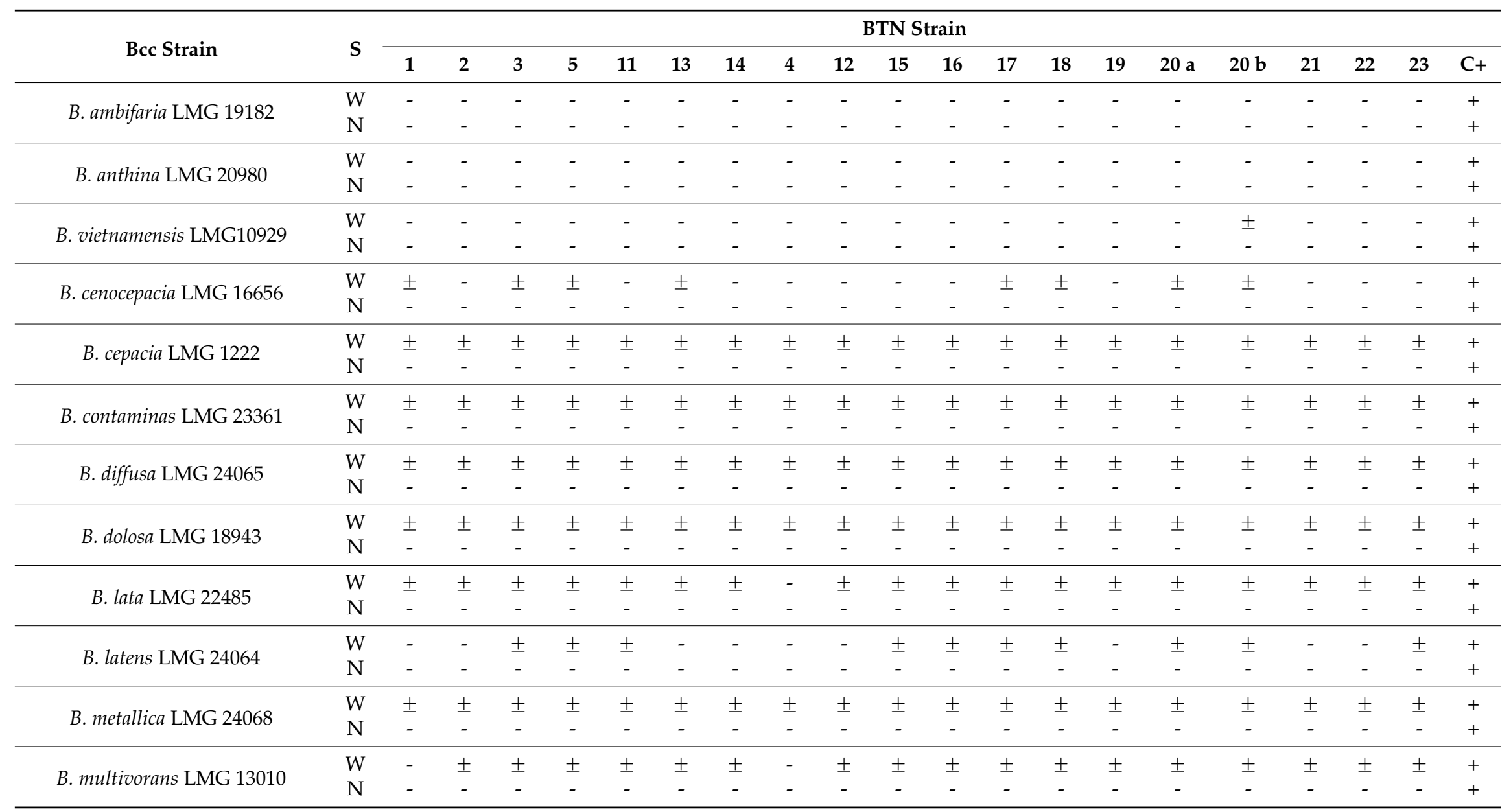


Table 2. Cont

\begin{tabular}{|c|c|c|c|c|c|c|c|c|c|c|c|c|c|c|c|c|c|c|c|c|c|}
\hline \multirow{2}{*}{ Bcc Strain } & \multirow{2}{*}{$\mathbf{S}$} & \multicolumn{19}{|c|}{ BTN Strain } & \multirow[b]{2}{*}{$\mathrm{C}+$} \\
\hline & & 1 & 2 & 3 & 5 & 11 & 13 & 14 & 4 & 12 & 15 & 16 & 17 & 18 & 19 & 20 a & $20 \mathrm{~b}$ & 21 & 22 & 23 & \\
\hline \multirow{2}{*}{ B. pseudomultivorans LMG 26883} & $\mathrm{~W}$ & \pm & \pm & \pm & \pm & \pm & \pm & \pm & \pm & \pm & \pm & \pm & \pm & \pm & \pm & \pm & \pm & \pm & \pm & \pm & + \\
\hline & $\mathrm{N}$ & - & - & - & - & - & - & - & - & - & - & - & - & - & - & - & - & - & - & - & + \\
\hline \multirow{2}{*}{ B. pyrrocinia LMG 14191} & $\mathrm{~W}$ & \pm & \pm & \pm & \pm & \pm & \pm & \pm & \pm & \pm & \pm & \pm & \pm & \pm & \pm & \pm & \pm & \pm & \pm & \pm & + \\
\hline & $\mathrm{N}$ & - & - & - & - & - & - & - & - & - & - & - & - & - & - & - & - & - & - & - & + \\
\hline \multirow{2}{*}{ B. seminalis LMG 24067} & $\mathrm{~W}$ & - & \pm & \pm & \pm & \pm & \pm & \pm & - & \pm & - & \pm & \pm & \pm & \pm & \pm & - & \pm & \pm & \pm & + \\
\hline & $\mathrm{N}$ & - & - & - & - & - & - & - & - & - & - & - & - & - & - & - & - & - & - & - & + \\
\hline \multirow{2}{*}{ B. stabilis LMG 14294} & $\mathrm{~W}$ & \pm & \pm & \pm & \pm & \pm & \pm & \pm & \pm & \pm & \pm & \pm & \pm & \pm & \pm & \pm & - & \pm & \pm & \pm & + \\
\hline & $\mathrm{N}$ & - & - & - & - & - & - & - & - & - & - & - & - & - & - & - & - & - & - & - & + \\
\hline \multirow{2}{*}{ B. uborrensis LMG 20358} & $\mathrm{~W}$ & - & - & \pm & \pm & \pm & \pm & \pm & - & \pm & \pm & \pm & \pm & \pm & - & \pm & \pm & \pm & \pm & \pm & + \\
\hline & $\mathrm{N}$ & - & - & - & - & - & - & - & - & - & - & - & - & - & - & - & - & - & - & - & + \\
\hline
\end{tabular}




\subsection{Extracts' Antimicrobial Assays}

Eight of the most active Antarctic strains belonging to the three different genera (Pseudomonas, Psychrobacter, and Arthrobacter) were selected and used to produce extracts, which were then tested against a reduced panel of Bcc type-strains isolated from CF patients. The MIC assays were carried out as described in Materials and Methods. Table 3 reports the antimicrobial activity as percentage of Bcc growth inhibition in the presence of each extract at a concentration of $1 \mathrm{mg} / \mathrm{mL}$.

Table 3. Antimicrobial activity of BTN cell extracts reported as \% of inhibition of Bcc strains treated with $1 \mathrm{mg} / \mathrm{mL}$ of BTN extracts.

\begin{tabular}{|c|c|c|c|c|c|c|c|c|c|}
\hline \multirow[b]{2}{*}{ Species } & \multirow[b]{2}{*}{ Strain } & \multirow{2}{*}{$\begin{array}{c}\text { Pseudomonas } \\
\text { BTN } 1\end{array}$} & \multicolumn{5}{|c|}{ Psychrobacter } & \multicolumn{2}{|c|}{ Arthrobacter } \\
\hline & & & BTN 2 & BTN 15 & BTN 3 & BTN 19 & BTN 21 & BTN 5 & BTN 4 \\
\hline B. diffusa & $\begin{array}{l}\text { LMG } \\
24065\end{array}$ & $100 \pm 0$ & $75 \pm 3$ & $77 \pm 3$ & $43 \pm 7$ & $45 \pm 11$ & $70 \pm 4$ & $77 \pm 9$ & $63 \pm 3$ \\
\hline B. metallica & $\begin{array}{c}\text { LMG } \\
24068\end{array}$ & $92 \pm 4$ & $70 \pm 5$ & $71 \pm 3$ & $32 \pm 2$ & $30 \pm 3$ & $53 \pm 5$ & $77 \pm 4$ & $64 \pm 9$ \\
\hline B. сепосерасіа & $\begin{array}{c}\text { LMG } \\
16656\end{array}$ & $100 \pm 0$ & $78 \pm 2$ & $87 \pm 1$ & $84 \pm 6$ & $64 \pm 4$ & $45 \pm 1$ & $84 \pm 2$ & $57 \pm 1$ \\
\hline B. latens & $\begin{array}{l}\text { LMG } \\
24064\end{array}$ & $100 \pm 0$ & $53 \pm 11$ & $75 \pm 2$ & $55 \pm 6$ & $43 \pm 3$ & $65 \pm 2$ & $56 \pm 3$ & $41 \pm 2$ \\
\hline B. seminalis & $\begin{array}{l}\text { LMG } \\
24067\end{array}$ & $100 \pm 0$ & $43 \pm 6$ & $67 \pm 5$ & $73 \pm 8$ & $45 \pm 6$ & $78 \pm 11$ & $40 \pm 3$ & $56 \pm 3$ \\
\hline
\end{tabular}

Data obtained revealed that the extracts were differentially active against the selected Bcc strains. Three Antarctic bacterial strains, i.e., BTN2, BTN15, and BTN5, were able to inhibit at least three of the five Bcc strains more than 70\% of growth. However, the extract from Pseudomonas BTN1 exhibited the best anti-Bcc activity; indeed, it was able to almost completely inhibit the growth of all the target strains at the concentration used. For this reason, this strain was selected for further scale-up and extract purification.

\subsection{Bioassay-Guided Purification of BTN1 Extract}

Pseudomonas sp. BTN1 strain was grown in $3 \mathrm{~L}$ TYP medium for five days at $20^{\circ} \mathrm{C}$; then, the culture broth was extracted with ethyl acetate. Subsequently, the crude extract $(1 \mathrm{~g})$ was fractionated with an SPE C18 Cartridge. Elution was performed stepwise with an increasing methanol concentration. The four eluted fractions were collected, dried and dissolved in DMSO to perform bioassay at a stock concentration of $50 \mathrm{mg} / \mathrm{mL}$. The fraction eluted at $100 \%$ methanol was shown to be the most active one against $B$. cenocepacia LMG 16656 with a MIC of $50 \mu \mathrm{g} / \mathrm{mL}$ and was subjected to HPLC separation. HPLC chromatograms extracted from 200 to $400 \mathrm{~nm}$ presented 11 different peaks, which were separated, dried and dissolved in DMSO at a stock concentration of $10 \mathrm{mg} / \mathrm{mL}$ to perform MIC assay. Data obtained revealed promising inhibitory activity against B. cenocepacia strain LMG 16656 of three compounds, hereinafter referred to as Compound 1, 2 and 3, respectively.

\subsection{Compound Structure Elucidation}

Compounds structures are shown in Figure 1. The molecular formula of compound 1 was established as $\mathrm{C}_{28} \mathrm{H}_{52} \mathrm{O}_{9}$ by HRESIMS (555.3514 $\Delta 0.92 \mathrm{ppm}[\mathrm{M}+\mathrm{Na}]^{+}$. Dereplication of this compound based on 1D, 2D NMR and LC-MS data indicated that it is a known rhamnolipid [24] containing two fully saturated lipid chains. The chain lengths of lipids A and B of compound 1 contained 10 and 12 carbons respectively were confirmed by analysis of MS/MS fragmentation data (Figure S19). The molecular formula of compound 2 was established as $\mathrm{C}_{28} \mathrm{H}_{50} \mathrm{O}_{9}$ by high-resolution electrospray ionization mass spectrometry (HRESIMS) (553.3343 $\Delta-0.75 \mathrm{ppm}[\mathrm{M}+\mathrm{Na}]^{+}$) and subsequent dereplication suggested it was new. The molecular formula suggested four degrees of unsaturation. 


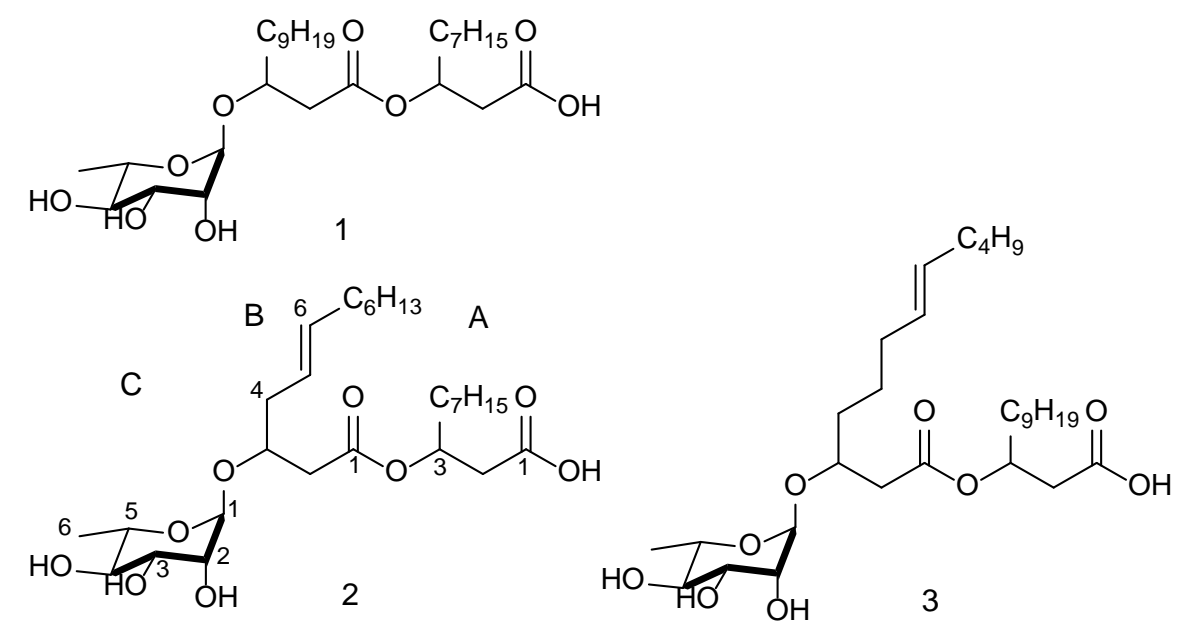

Figure 1. Structures of the three rhamnolipids isolated from Pseudomonas BTN1.

The ${ }^{1} \mathrm{H},{ }^{13} \mathrm{C}$-NMR data (Table 1$)$ in $\mathrm{CD}_{3} \mathrm{OD}$ of 2 revealed one ester $\left(\delta_{\mathrm{C}} 173.4 \mathrm{ppm}\right)$, one carboxylic acid group $\left(\delta_{C} 171.40\right) \mathrm{ppm}$, two olefinic carbons $\left(\delta_{C} 132.8,123.7 \mathrm{ppm}\right)$, and an anomeric carbon $\left(\delta_{\mathrm{C}} 98.47 \mathrm{ppm}\right)$ of a sugar unit. This analysis accounted for three of the double bond equivalents, suggesting that the sugar unit was present as a ring. The structure of compound $\mathbf{2}$ was elucidated based on 2D NMR correlation experiments. Data clearly showed three distinctive spin systems. There were COSY correlations observed between the anomeric proton and the adjacent protons of the sugar unit. There was a strong observed COSY correlation between the methyl group at $\delta_{\mathrm{H}} 1.27 \mathrm{ppm}$ and the proton at $\delta_{\mathrm{H}} 3.38 \mathrm{ppm}$ placing the methyl group at position $\mathrm{C} 5$. The proposed structure was fully supported by COSY and HMBC correlations (Table 4 and Figure S10) indicating that compound 2 is a rhamnolipid with the $\mathrm{A}$ and $\mathrm{B}$ chains having 10 and 12 carbons respectively, and a single unsaturation at position B5. Further evidence supporting the structure came from careful interpretation of MS/MS fragmentation data (Figure S21). The relative orientation of the rhamnose moiety in compound 2 was identified as $\alpha$ based on detailed analysis of ROE data (2D ROESY), chemical shifts and proton coupling constants [24,25]. Analysis of ROESY data showed an ROE correlation between H-1 and $\mathrm{H}-2$ suggesting that both occupied equatorial positions. This is in agreement with the observed small coupling constant ${ }^{3} J(1,2)$ of about $1.4 \mathrm{~Hz}$ in $\mathrm{CD}_{3} \mathrm{OD}$ and a broad singlet in DMSO- $\mathrm{D}_{6}$. A ROE correlation between $\mathrm{H}-3$ and H-5 suggested that both were in axial positions (Figure S13). In addition, ROE correlations were observed between $\mathrm{H}-3$ and $\mathrm{H}-2$ (axial-equatorial), $\mathrm{H}-6$ and $\mathrm{H}-5$ (equatorial-axial) and between $\mathrm{H}-6$ and H-4 (equatorial-axial). This conformation is in agreement with observed coupling constants: ${ }^{3} J(2,3,3.5 \mathrm{~Hz}),{ }^{3} J(3,5,9.5 \mathrm{~Hz})$ and ${ }^{3} J(4,5,9.8 \mathrm{~Hz})$. All the data is consistent with the rhamnose unit oriented in a $\alpha$ position. A 2D ROESY NMR spectrum is available in the supporting information (Figure S12).

The molecular formula of compound 3 was established as $\mathrm{C}_{30} \mathrm{H}_{54} \mathrm{O}_{9}$ by HRESIMS 581.3649 $\Delta 1.72 \mathrm{ppm}[\mathrm{M}+\mathrm{Na}]^{+}$. Based on 1D, 2D NMR and LC-MS data compound 3 was similar to 2, the difference being an additional $\mathrm{C}_{2} \mathrm{H}_{4}$ unit. However, careful interpretation of the data indicated that both the lipid chains A and B were $\mathrm{C} 12$ carbons with a single unsaturation at position B7 instead of $\mathrm{C} 10$ and $\mathrm{C} 12$ carbons and an unsaturation position at B5 in 2. Further evidence of this structure came from MS/MS fragmentation data (Figure S23). The relative configuration of the rhamnose unit was similar to that of compounds $\mathbf{1}$ and $\mathbf{2}$ based on similarities of chemical shifts and proton coupling constants. In all three compounds, it is assumed that the rhamnose moieties have the normal L-configuration. In addition, the absolute stereochemistry of position H-3 in the lipid chains A and B have not been determined. 
Table 4. NMR data of 2 and 3 in $\mathrm{CD}_{3} \mathrm{OD} .^{\mathrm{a}} 150 \mathrm{MHz}{ }^{\mathrm{b}} 600 \mathrm{MHz}$.

\begin{tabular}{|c|c|c|c|c|c|c|c|c|c|}
\hline & & 2 & & & & 3 & & & \\
\hline \multirow{13}{*}{ A } & Position & ${ }^{\mathrm{TM}} \mathrm{C} / \mathrm{ppm}^{\mathrm{a}}, \mathrm{m}$ & ${ }^{\mathrm{TM}} \mathrm{H} / \mathrm{ppm}(\mathrm{m}, J \text { in } \mathrm{Hz})^{\mathrm{b}}$ & $\operatorname{COSY}{ }^{1} \mathrm{H}-{ }^{1} \mathrm{H}$ & $\mathrm{HMBC} \mathrm{H} \rightarrow \mathrm{C}$ & ${ }^{\mathrm{TM}} \mathrm{C} / \mathrm{ppm}^{\mathrm{a}}, \mathrm{m}$ & ${ }^{\mathrm{TM}} \mathrm{H} / \mathrm{ppm}(\mathrm{m}, J \text { in } \mathrm{Hz})^{\mathrm{b}}$ & $\operatorname{COSY}{ }^{1} \mathrm{H}-{ }^{1} \mathrm{H}$ & $\mathrm{HMBC} \mathrm{H} \rightarrow \mathrm{C}$ \\
\hline & 1 & & & & & & & & \\
\hline & 2 & $38.9, \mathrm{CH}_{2}$ & $2.58, \mathrm{~m}$ & A3 & A1 & $40.9, \mathrm{CH}_{2}$ & $2.54, \mathrm{~m}$ & A3 & A1 \\
\hline & 3 & $71.1, \mathrm{CH}$ & 5.27 , pentet, 6.4 & $\mathrm{~A} 2, \mathrm{~A} 3$ & $\mathrm{~A} 1, \mathrm{~A} 2$ & $72.7, \mathrm{CH}$ & 5.29 , pentet, 6.5 & $\mathrm{~A} 2, \mathrm{~A} 4$ & $\mathrm{~A} 1, \mathrm{~A} 2$ \\
\hline & 4 & $33.8, \mathrm{CH}_{2}$ & $1.64, \mathrm{~m}$ & A3 & A3 & $34.9, \mathrm{CH}_{2}$ & $1.63, \mathrm{bm}$ & A3 & A3 \\
\hline & 5 & $24.9, \mathrm{CH}_{2}$ & 1.35 , overlap & & & 26.0, $\mathrm{CH}_{2}$ & 1.35 , overlap & & \\
\hline & 6 & $29.3, \mathrm{CH}_{2}$ & 1.31 , overlap & & & $30.5, \mathrm{CH}_{2}$ & 1.37 , overlap & & \\
\hline & 7 & $29.3, \mathrm{CH}_{2}$ & 1.31 , overlap & & & $30.1, \mathrm{CH}_{2}$ & 1.32 , overlap & & \\
\hline & 8 & 31. $6, \mathrm{CH}_{2}$ & 1.31 , overlap & & & $29.8, \mathrm{CH}_{2}$ & 1.33 , overlap & & \\
\hline & 9 & $22.3, \mathrm{CH}_{2}$ & 1.33 , overlap & A10 & A10 & $30.2, \mathrm{CH}_{2}$ & 1.36 , overlap & A10 & A10 \\
\hline & 10 & $13.1, \mathrm{CH}_{3}$ & $0.92, \mathrm{~m}$ & A9 & A9 & $32.7, \mathrm{CH}_{2}$ & 1.31 , overlap & A9 & A9 \\
\hline & 11 & & & & & $23.4, \mathrm{CH}_{2}$ & 1.33, overlap & & \\
\hline & 12 & & & & & $14.1, \mathrm{CH}_{3}$ & $0.92, \mathrm{~m}$ & & \\
\hline \multirow[t]{12}{*}{ B } & 1 & $171.4, \mathrm{C}$ & & & & $172.3, \mathrm{CH}$ & & & \\
\hline & 2 & $39.5, \mathrm{CH}_{2}$ & $2.53, \mathrm{~m}$ & B3 & B1 & 41.0, $\mathrm{CH}_{2}$ & $\begin{array}{l}\text { A: } 2.60, \mathrm{~m} \\
\text { B: } 2.50, \mathrm{~m}\end{array}$ & B3 & B1 \\
\hline & 3 & $72.9, \mathrm{CH}$ & 4.16 , pentet, 5.8 & $\mathrm{~B} 2, \mathrm{~B} 4$ & B1, B5 & $74.8, \mathrm{CH}$ & 4.10 , pentet, 5.9 & B2, B4 & B1, B5 \\
\hline & 4 & $30.4, \mathrm{CH}_{2}$ & $\begin{array}{l}\text { A: } 2.39, \mathrm{~m} \\
\text { B: } 2.33, \mathrm{~m}\end{array}$ & B3, B5 & B3, B5 & $33.5, \mathrm{CH}_{2}$ & $1.58, \mathrm{bm}$ & B3,B5 & B3, B5 \\
\hline & 5 & 123.7, CH & $5.40, \mathrm{~m}$ & B4, B6 & B3, B4, B6, B7 & 25.7, $\mathrm{CH}_{2}$ & 1.43, overlap & B4, B6 & \\
\hline & 6 & $132.8, \mathrm{CH}$ & $5.55, \mathrm{~m}$ & B5, B7 & B5, B8 & $27.8, \mathrm{CH}_{2}$ & 2.08, overlap & B5, B7 & \\
\hline & 7 & 27.1, $\mathrm{CH}_{2}$ & $2.08, \mathrm{~m}$ & B6 & $\mathrm{B} 5, \mathrm{~B} 6$ & 130.0, $\mathrm{CH}$ & $5.37, \mathrm{~m}$ & B6, B8 & B8, B6, B9 \\
\hline & 8 & $29.3, \mathrm{CH}_{2}$ & 1.31 , overlap & & & 131.2, $\mathrm{CH}$ & $5.39, \mathrm{~m}$ & B7 & B7 \\
\hline & 9 & $28.9, \mathrm{CH}_{2}$ & 1.33, overlap & B7 & & 32. $7, \mathrm{CH}_{2}$ & 1.31 , overlap & B8 & \\
\hline & 10 & $31.6, \mathrm{CH}_{2}$ & 1.31 , overlap & & & $32.7, \mathrm{CH}_{2}$ & 1.31 , overlap & & \\
\hline & 11 & $22.3, \mathrm{CH}_{2}$ & 1.33, overlap & & B12 & 23.4, $\mathrm{CH}_{2}$ & 1.33, overlap & B12 & \\
\hline & 12 & $13.1, \mathrm{CH}_{3}$ & $0.92, \mathrm{~m}$ & & B11 & $14.1, \mathrm{CH}_{3}$ & $0.92, \mathrm{~m}$ & B11 & \\
\hline \multirow[t]{6}{*}{ C } & 1 & $98.5, \mathrm{CH}$ & 4.86 , overlap & $\mathrm{C} 2$ & $\mathrm{~B} 3, \mathrm{C} 2$ & 100.0, CH & $4.80, \mathrm{~d}, 1.4$ & $\mathrm{C} 2$ & $\mathrm{~B} 3, \mathrm{C} 2$ \\
\hline & 2 & $71.2, \mathrm{CH}$ & $3.77, \mathrm{dd}, 3.5,1.4$ & $\mathrm{C} 1, \mathrm{C} 3$ & $\mathrm{C} 3, \mathrm{C} 4$ & $72.4, \mathrm{CH}$ & $3.76, \mathrm{dd}, 3.4,1.4$ & $\mathrm{C} 1, \mathrm{C} 3$ & $\mathrm{C} 3, \mathrm{C} 4$ \\
\hline & 3 & $70.9, \mathrm{CH}$ & $3.64, \mathrm{dd}, 9.5,3.5$ & $\mathrm{C} 2, \mathrm{C} 4$ & C5 & $71.9, \mathrm{CH}$ & $3.66, \mathrm{dd}, 9.7,3.4$ & $\mathrm{C} 2, \mathrm{C} 4$ & C5 \\
\hline & 4 & $72.7, \mathrm{CH}$ & $3.38, \mathrm{dd}, 9.5,9.8$ & $\mathrm{C} 3, \mathrm{C} 5$ & $\mathrm{C} 3$ & $73.8, \mathrm{CH}$ & $3.35, \mathrm{dd}, 9.7,9.8$ & $\mathrm{C} 3, \mathrm{C} 5$ & $\mathrm{C} 3$ \\
\hline & 5 & $68.7, \mathrm{CH}$ & $3.67, \mathrm{~m}$ & $\mathrm{C} 4, \mathrm{C} 6$ & $\mathrm{C} 4, \mathrm{C} 6$ & $69.8, \mathrm{CH}$ & $3.68, \mathrm{~m}$ & $\mathrm{C} 4, \mathrm{C} 6$ & $\mathrm{C} 4, \mathrm{C} 6$ \\
\hline & 6 & $16.6, \mathrm{CH}_{3}$ & $1.27, \mathrm{~d}, 6.2$ & C5 & C5 & 17.6, $\mathrm{CH}_{3}$ & $1.27, \mathrm{~d}, 6.3$ & C5 & C5 \\
\hline
\end{tabular}




\subsection{Antimicrobial Activity of BTN1 Pure Compounds}

The three monorhamnolipids isolated from strain BTN1 were tested against a selected panel of Bcc strains isolated from CF patients and S. aureus. MIC and MBC values are reported in Table 5. It is worth noticing that the three compounds have identical MIC and MBC values indicating a bactericidal effect against the target bacteria, as reported for several natural biosurfactants [26,27]. Compounds 2 and $\mathbf{1}$ were the most active compounds as they were effective against all the tested stains, with the only exception of $B$. diffusa. Specifically, compounds $\mathbf{2}$ and $\mathbf{1}$ had the lowest $\mathrm{MBC}$ values against $B$. cenocepacia $(3.12 \mu \mathrm{g} / \mathrm{mL})$ and S. aureus (respectively, 3.12 and $1.56 \mu \mathrm{g} / \mathrm{mL})$. Compound 3 had antimicrobial effect only against $S$. aureus with an MBC value of $100 \mu \mathrm{g} / \mathrm{mL}$, while it resulted in being ineffective towards Bcc strains. Rhamnolipids (RLs) are well-known secondary metabolites synthesized by members of different Gram-negative species, particularly from bacteria belonging to the genus Pseuedomonas. They perform several potential functions in bacteria: as powerful biosurfactants, they are involved in the uptake and $b$ tested stains, with the only exception of polymerase and 0.6 iodegradation of poorly soluble substrates and are essential for surface motility and biofilm development [28]. Recently, they have emerged as potential antimicrobials against a broad range of pathogens such as Staphylococcus, Mycobacterium, and Bacillus, and significant activity against a number of Gram-negative species, including Serratia marcescens, Enterobacter aerogenes, and Klebsiella pneumoniae [29-31]. RLs act like synthetic surfactants and their proposed mechanism of action consists of intercalation into biological membranes and destruction by their permeabilizing effect leading to cell death [32].

Table 5. MIC and MBC values of the 3 mono-rhamnolipids isolated in this study.

\begin{tabular}{|c|c|c|c|c|c|c|c|c|c|c|c|c|}
\hline \multicolumn{13}{|c|}{ Antimicrobial Activity $(\mu \mathrm{g} / \mathrm{mL})$} \\
\hline & \multirow{2}{*}{\multicolumn{2}{|c|}{$\begin{array}{l}\text { B. cenocepacia } \\
\text { LMG } 16656\end{array}$}} & \multirow{2}{*}{\multicolumn{2}{|c|}{$\begin{array}{l}\text { B. metallica } \\
\text { LMG } 24068\end{array}$}} & \multirow{2}{*}{\multicolumn{2}{|c|}{$\begin{array}{l}\text { B. seminalis } \\
\text { LMG } 24067\end{array}$}} & \multirow{2}{*}{\multicolumn{2}{|c|}{$\begin{array}{c}\text { B. diffusa } \\
\text { LMG } 24065\end{array}$}} & \multirow{2}{*}{\multicolumn{2}{|c|}{$\begin{array}{l}\text { B. latens LMG } \\
24064\end{array}$}} & \multirow{2}{*}{\multicolumn{2}{|c|}{$\begin{array}{l}\text { S. aureus } \\
6538 \mathrm{P}\end{array}$}} \\
\hline & & & & & & & & & & & & \\
\hline & MIC & $\mathrm{MBC}$ & MIC & $\mathrm{MBC}$ & MIC & $\mathrm{MBC}$ & MIC & $\mathrm{MBC}$ & MIC & $\mathrm{MBC}$ & MIC & $\mathrm{MBC}$ \\
\hline $\mathrm{C} 1$ & 3.12 & 3.12 & 50 & 50 & 12.5 & 12.5 & $>200$ & $>200$ & 12.5 & 12.5 & 1.56 & 1.56 \\
\hline $\mathrm{C} 2$ & 3.12 & 3.12 & 25 & 25 & 3.12 & 3.12 & 200 & 200 & 12.5 & 12.5 & 3.12 & 3.12 \\
\hline $\mathrm{C} 3$ & 200 & 200 & $>200$ & $>200$ & $>200$ & $>200$ & $>200$ & $>200$ & $>200$ & $>200$ & 100 & 100 \\
\hline
\end{tabular}

\section{Experimental Section}

\subsection{Isolation of Bacterial Strains}

The Antarctic bacterial strains used in this study were isolated from environmental samples collected at $-20 \mathrm{~m}$ of depth (sub-sea sediments) near the Mario Zucchelli Station, Baia Terranova, Ross sea, Antarctica $\left(74.6936^{\circ} \mathrm{S}, 164.1117^{\circ} \mathrm{E}\right) .1$ gr of sediments was mixed with $20 \mathrm{~mL}$ of M9 salts solution $\left(\mathrm{KH}_{2} \mathrm{PO}_{4} 3.0 \mathrm{~g} / \mathrm{L}, \mathrm{Na}_{2} \mathrm{HPO}_{4} 6.0 \mathrm{~g} / \mathrm{L}, \mathrm{NaCl} 0.5 \mathrm{~g} / \mathrm{L}, \mathrm{NH}_{4} \mathrm{Cl} 1.0 \mathrm{~g} / \mathrm{L}\right)$ in a $50 \mathrm{~mL}$ Falcon tube and gently mixed; the supernatant was serially diluted in sterile $\mathrm{M} 9$ buffer and plated on PYG medium (Peptone $5.0 \mathrm{~g} / \mathrm{L}$, Yeast extract $4.0 \mathrm{~g} / \mathrm{L}$, Glucose $1.0 \mathrm{~g} / \mathrm{L}, \mathrm{CaCl}_{2} 0.2 \mathrm{~g} / \mathrm{L}, \mathrm{MgSO}_{4} .7 \mathrm{H}_{2} \mathrm{O} 0.4 \mathrm{~g} / \mathrm{L}, \mathrm{K}_{2} \mathrm{HPO}_{4} 1.0 \mathrm{~g} / \mathrm{L}$, $\mathrm{KH}_{2} \mathrm{PO}_{4} 1.0 \mathrm{~g} / \mathrm{L}, \mathrm{NaHCO}_{3} 10.0 \mathrm{~g} / \mathrm{L} \mathrm{NaCl} 2.0 \mathrm{~g} / \mathrm{L}$ and $17 \mathrm{~g} / \mathrm{L}$ ). After 15 days of incubation, 24 visible colonies were picked, grown in liquid PYG and stored at $-80^{\circ} \mathrm{C}$.

\subsection{Target Strains and Growth Conditions}

Bcc strains used in this work are listed in Table 2 and Table S1. Bcc and S. aureus 6538P were routinely grown on Luria-Bertani broth (LB) (Tryptone $10 \mathrm{~g} / \mathrm{L}$, Yeast extract $5 \mathrm{~g} / \mathrm{L}, \mathrm{NaCl} 10 \mathrm{~g} / \mathrm{L}$ ) at $37^{\circ} \mathrm{C}$. BTN isolated Antactic strains were routinely grown in TYP medium (Bacto-tryptone $16 \mathrm{~g} / \mathrm{L}$, $16 \mathrm{~g} / \mathrm{L}$ Yeast extract, $10 \mathrm{~g} / \mathrm{L} \mathrm{NaCl}$ ) and Marine Broth (MB) at $21^{\circ} \mathrm{C}$. To allow bacterial growth on solid media, $17 \mathrm{~g} / \mathrm{L}$ of bacteriological agar were added to each medium. 


\subsection{RAPD Analysis}

Typing of bacterial isolates was performed using the Random Amplified Polymorphic DNA (RAPD) technique performed on cell lysates [33-35]; to this purpose, Antarctic bacterial colonies grown overnight at $21^{\circ} \mathrm{C}$ on MA plates were suspended in $25 \mu \mathrm{L}$ of sterile distilled water, heated to $95^{\circ} \mathrm{C}$ for $10 \mathrm{~min}$, and cooled on ice for $5 \mathrm{~min}$. RAPD analysis was carried out in a total volume of $25 \mu \mathrm{L}$ containing $1 \times$ Reaction Buffer, $300 \mu \mathrm{M} \mathrm{MgCl}_{2}, 200 \mu \mathrm{M}$ of each deoxynucleoside triphosphate, $0.5 \mathrm{U}$ of Polytaq DNA polymerase (Polymed, Florence, Italy), $10 \mu \mathrm{M}$ of primer 1253 (5'GTTTCCGCCC $\left.3^{\prime}\right)$ or primer AP5 (5'TCACGCTGCG3') and $2 \mu \mathrm{L}$ of lysate cell suspension [35]. PCR were performed using MasterCycle Personal Thermal Cycler (Eppendorf, Hamburg, Germany). After incubation at $90{ }^{\circ} \mathrm{C}$ for $1 \mathrm{~min}$ and $95^{\circ} \mathrm{C}$ for $1.5 \mathrm{~min}$, the reaction mixtures were cycled 45 times through the following temperature profile: $95^{\circ} \mathrm{C}$ for $30 \mathrm{~s}, 36^{\circ} \mathrm{C}$ for $1 \mathrm{~min}$, and $75^{\circ} \mathrm{C}$ for $1 \mathrm{~min}$. Samples were then incubated at $60^{\circ} \mathrm{C}$ for $10 \mathrm{~min}$, and finally at $5^{\circ} \mathrm{C}$ for $10 \mathrm{~min}$. Amplification products were then stored at $-20^{\circ} \mathrm{C}$. Reaction products were analyzed by agarose $(2.5 \% w / v)$ gel electrophoresis in TAE buffer containing $0.5 \mu \mathrm{g} / \mathrm{mL}(w / v)$ of ethidium bromide.

\subsection{Phylogenetic Affiliation of BTN Strains}

Two $\mu \mathrm{L}$ of each cell lysate were used for the amplification via PCR of $16 \mathrm{~S}$ rRNA genes. PCR was carried out in a total volume of $50 \mu \mathrm{L}$ containing 1X Reaction Buffer, $150 \mu \mathrm{M} \mathrm{MgCl}_{2}, 250 \mu \mathrm{M}$ of each deoxynucleoside triphosphate, and $2.0 \mathrm{U}$ of Polytaq DNA polymerase and $0.6 \mu \mathrm{M}$ of primer P0 ( $5^{\prime}$ GAGAGTTTGATCCTGGCTCAG3') and P6 (5'CTACGGCTACCTTGTTACGA3') [36]. The reaction conditions used were: one cycle $\left(95^{\circ} \mathrm{C}\right.$ for $\left.90 \mathrm{~s}\right), 30$ cycles $\left(95^{\circ} \mathrm{C} 30 \mathrm{~s}, 50{ }^{\circ} \mathrm{C} 30 \mathrm{~s}\right.$, and $\left.72{ }^{\circ} \mathrm{C} 1 \mathrm{~min}\right)$, with a final extension of $10 \mathrm{~min}$ at $72{ }^{\circ} \mathrm{C}$. Amplicons corresponding to the $16 \mathrm{~S}$ rRNA genes (observed under UV light, $312 \mathrm{~nm}$ ) were excised from the gel and purified using the "QIAquick" gel extraction kit (QIAGEN, Chatsworth, CA, USA) according to manufacturer's instructions. Direct sequencing was performed on both DNA strands using an ABI PRISM 310 Genetic Analyzer (Applied Biosystems, Forster City, CA, USA) and the chemical dye terminator [37]. Each 16S rRNA gene sequence was submitted to GenBank and assigned the accession number shown in Table 1. BLAST probing of DNA databases was performed with the BLASTn option of the BLAST program using default parameters [38]. Nucleotide sequences were retrieved from RDP databases. The ClustalW program was used to align the 16S rRNA gene sequences obtained with the most similar ones retrieved from the databases [39]. Each alignment was checked manually, corrected, and then analyzed. The evolutionary history was inferred using the Neighbor-Joining method according to the model of Kimura two-parameter distances [40,41]. The percentage of replicate trees where the associated taxa clustered together in the bootstrap test (1000 replicates) is shown next to the branches [42].

\subsection{Cross-Streaking}

Cross-streaking experiments were carried out as previously described [11]. Petri dishes with or without a septum separating two hemi-cycles were used. Plates with a central septum allowed the growth of tester and target strains without any physical contact. Antarctic strains (tester strains) were grown on MA for four days at $21^{\circ} \mathrm{C}$; then, they were streaked on TYP and incubated at $21^{\circ} \mathrm{C}$ for four days. Bcc strains (target strains) were perpendicularly streaked to the initial streak and plates were further incubated at $21^{\circ} \mathrm{C}$ for two days and at $37^{\circ} \mathrm{C}$ for two additional days. The experiments were conducted in parallel with a positive control to verify the viability of Bcc cells.

\subsection{Extract Preparation}

A single colony of a bacterial isolate was used to inoculate $3 \mathrm{~mL}$ of liquid TYP media in sterile bacteriological tubes. After $48 \mathrm{~h}$ of incubation at $21^{\circ} \mathrm{C}$ at $200 \mathrm{rpm}$, the pre-inoculum was used to inoculate $100 \mathrm{~mL}$ of TYP medium in a $500 \mathrm{~mL}$ flask, at an initial cell concentration of $0.01 \mathrm{OD}_{600} / \mathrm{mL}$. The flasks were incubated up to five days at $21^{\circ} \mathrm{C}$ at $200 \mathrm{rpm}$. The cultures were then centrifuged 
at $6800 \times g$ at $4{ }^{\circ} \mathrm{C}$ for $30^{\prime}$, and the exhausted culture broths were collected and stored at $-20{ }^{\circ} \mathrm{C}$. The exhausted culture broths were subjected to organic extraction using three volumes of ethyl acetate in a $500 \mathrm{~mL}$ separatory funnel. The organic phase collected was evaporated using a Laborota 4000 rotary evaporator (Heidolph, Schwabach, Germany), and the extracts were weight, dissolved in $100 \%$ DMSO at 50 or $100 \mathrm{mg} / \mathrm{mL}$ and stored at $-20^{\circ} \mathrm{C}$.

\subsection{Antimicrobial Assays}

\subsubsection{Minimal Inhibitory Concentration Assay (MIC)}

To evaluate the antimicrobial potential of Antarctic extracts, samples were placed into each well of a 96-well microtiter plate at an initial concentration of $2 \%(v / v)$ and serially diluted using LB medium. Wells containing no compound represented the negative control. DMSO was used as control to determine the effect of solvent on cell growth. A single colony of a Bcc strain was used to inoculate $3 \mathrm{~mL}$ of liquid LB media in sterile bacteriological tube. After 6-8 h of incubation, growth was measured by monitoring the absorbance at $600 \mathrm{~nm}$ and about $40,000 \mathrm{CFU}$ were dispensed in each well of the prepared plate. Plates were incubated at $37^{\circ} \mathrm{C}$ for $24 \mathrm{~h}$ and growth was measured with a Cytation 3 Plate Reader (Biotek, Winoosky, VT, USA) by monitoring the absorbance at $600 \mathrm{~nm}$.

\subsubsection{Minimal Bactericidal Concentration (MBC) Assay}

To determine the MBC, the dilution representing the MIC and two of the more concentrated test product dilutions were plated on LB agar plates and enumerated to determine $\mathrm{CFU} / \mathrm{mL}$. An aliquot of the positive control was plated and used to establish a baseline concentration of the microorganism used.

\subsection{Purification of Ethyl-Acetate Crude Extract}

Crude extract of 3 L BTN1 fermentation, prepared as described above, was subjected to fractionation using Chromabond SPE C18 column cartridges (Macherey-Nagel, Duren, Germany). HPLC separations were carried out using a VP 250/10 Nucleodur C18 HTec, $5 \mu \mathrm{m}$, (Macherey-Nagel Duren, Germany) connected to a Ultimate 3000 HPLC Chromatograph with a Ultimate 3000 Diode Array detector and in-line degasser (Dionex, Sunnyvale, CA, USA). Detection was achieved on-line through a scan of wavelengths from 200 to $400 \mathrm{~nm}$. This process yielded $4.8 \mathrm{mg}$ of $\mathbf{1}, 5.3 \mathrm{mg}$ of 2 and $5.7 \mathrm{mg}$ of 3 .

Compound 2. $[\alpha]_{\mathrm{D}}-53.4^{\circ}\left(c 0.001 \mathrm{MeOH} ; \mathrm{UV}(\mathrm{MeOH}) \lambda_{\max }(\log \varepsilon) 202\right.$ (3.55) nm; IR (film) vmax 3361, $2925,2855,1735,1671,1575,1455,1380,1314,1207,1161,1126,1037,983, \mathrm{~cm}^{-1} ;{ }^{1} \mathrm{H},{ }^{13} \mathrm{C}, \mathrm{HMBC}$ NMR data see Table 1; HRESIMS $m / z 553.3343 \Delta-0.75$ ppm $[\mathrm{M}+\mathrm{Na}]^{+}$calculated for $\mathrm{C}_{28} \mathrm{H}_{50} \mathrm{O}_{9}$.

Compound 3. $[\alpha]_{\mathrm{D}}+49.3^{\circ}\left(c 0.001 \mathrm{MeOH} U \mathrm{UV}(\mathrm{MeOH}) \lambda_{\max }(\log \varepsilon) 202\right.$ (3.78) nm; IR (film) vmax 3387, 2926, 2855, 1667, 1587, 1402, 1316, 1204, 1130, 1072, 1049, $983 \mathrm{~cm}^{-1} ;{ }^{1} \mathrm{H},{ }^{13} \mathrm{C}, \mathrm{HMBC}$ NMR data see Table 1 ; HRESIMS $m / z 581.3649 \Delta 1.72 \mathrm{ppm}[\mathrm{M}+\mathrm{Na}]^{+}$calculated for $\mathrm{C}_{30} \mathrm{H}_{54} \mathrm{O}_{9}$.

\subsection{NMR-LCMS Experiments}

NMR data, both 1D and 2D were recorded on a spectrometer (Bruker, Billerica, MA, USA) at 600 and $150 \mathrm{MHz}$ for ${ }^{1} \mathrm{H}$ and ${ }^{13} \mathrm{C}$, respectively, using an ID cryoprobe in methanol- $\mathrm{d}_{4}$ as solvent. Chemical shifts are reported in parts per million $(\delta / \mathrm{ppm})$ downfield relative to residual $\mathrm{CD}_{3} \mathrm{OD}$ at $3.31 \mathrm{ppm}$ for protons and $49.0 \mathrm{ppm}$ for carbons. High-resolution mass spectrometry and fragmentation data were recorded using an LTQ Orbitrap system (ThermoScientific, Whaltman, MA, USA) coupled to an 1290 Infinity HPLC system (Agilent, Santa Clara, CA, USA). The following conditions were used: capillary voltage $45 \mathrm{~V}$, capillary temperature $320^{\circ} \mathrm{C}$, auxiliary gas flow rate $10-20$ arbitrary units, sheath gas flow rate 40-50 arbitrary units, spray voltage $4.5 \mathrm{kV}$, mass range 100-2000 amu (maximum 
resolution 30,000). Optical rotation measurements were recorded using a Perkin Elmer, Model 343 Polarimeter at $589 \mathrm{~nm}$ (Perkin Elmer, Whaltman, MA, USA). The UV spectrum was recorded on a UV-Vis spectrophotometer model S10 (Spectromlab, Barcelona, Spain). The IR was recorded on a PerkinElmer FTIR Spectrum Two instrument (Perkin Elmer, Whaltman, MA, USA).

\section{Conclusions}

Exploiting a bioassay-driven purification approach, three RLs (one of which was novel) with antimicrobial activity against Bcc strains, were isolated from Pseudomonas sp. BTN1, recovered from Antarctic sediments. RLs represent a promising class of biosurfactants as antimicrobials or in combination with antibiotics. A recent study suggested the use of RLs as an additive in the formulation of antibiotic and other antimicrobial agents for enhancing the effectiveness of chemotherapeutics [43]. Moreover, the possibility of RL production by the fermentation of organic waste (such us waste oils), makes these products economically appealing [44]. To the best of our knowledge, this is the first report of antimicrobial activity of RLs against Bcc strains, and it prompts future studies aimed at RL exploitation as drugs to counteract these hazardous opportunistic human pathogens.

Acknowledgments: This work was supported by the EU FP7 KBBE 2012-2016 project PharmaSea, grant $N^{\circ}$ 312184 and from the Italian Cystic Fibrosis Research foundation (Grant FFC\#12/2011).

Author Contributions: P.T., I.M., R.F., J.T., M.J. and D.D.P. conceived and designed the experiments; P.T., I.M., F.P.E., E.T., J.T., K.S., C.C.E., and Y.Z. performed the experiments; P.T., I.M., F.P.E., K.S., C.C.E., Y.Z. R.F., J.T., and D.D.P. analyzed the data; R.F., M.J. and D.D.P. contributed reagents/materials/analysis tools; P.T., I.M., F.P.E., J.T., R.F., M.J. and D.D.P. wrote the paper.

Conflicts of Interest: The authors declare no conflict of interest.

\section{References}

1. Berdy, J. Thoughts and facts about antibiotics: Where we are now and where we are heading. J. Antibiot. 2012, 65, 385-395. [CrossRef] [PubMed]

2. Tegos, G.P.; Hamblin, M.R. Disruptive innovations: New anti-infectives in the age of resistance. Curr. Opin. Pharmacol. 2013, 13, 673-677. [CrossRef] [PubMed]

3. Newman, D.J.; Cragg, G.M. Natural products as sources of new drugs over the 30 years from 1981 to 2010. J. Nat. Prod. 2012, 75, 311-335. [CrossRef] [PubMed]

4. Bologa, C.G.; Ursu, O.; Oprea, T.I.; Melancon, C.E., 3rd; Tegos, G.P. Emerging trends in the discovery of natural product antibacterials. Curr. Opin. Pharmacol. 2013, 13, 678-687. [CrossRef] [PubMed]

5. Zhu, F.; Ma, X.H.; Qin, C.; Tao, L.; Liu, X.; Shi, Z.; Zhang, C.L.; Tan, C.Y.; Chen, Y.Z.; Jiang, Y.Y. Drug discovery prospect from untapped species: Indications from approved natural product drugs. PLoS ONE 2012, 7, e39782. [CrossRef] [PubMed]

6. Jaspars, M.; Challis, G. Microbiology: A talented genus. Nature 2014, 506, 38-39. [CrossRef] [PubMed]

7. Von Salm, J.L.; Wilson, N.G.; Vesely, B.A.; Kyle, D.E.; Cuce, J.; Baker, B.J. Shagenes A and B, new tricyclic sesquiterpenes produced by an undescribed Antarctic octocoral. Org. Lett. 2014, 16, 2630-2633. [CrossRef] [PubMed]

8. Godinho, V.M.; Goncalves, V.N.; Santiago, I.F.; Figueredo, H.M.; Vitoreli, G.A.; Schaefer, C.E.; Barbosa, E.C.; Oliveira, J.G.; Alves, T.M.; Zani, C.L.; et al. Diversity and bioprospection of fungal community present in oligotrophic soil of continental Antarctica. Extremophiles 2015, 19, 585-596. [CrossRef] [PubMed]

9. Lee, L.H.; Cheah, Y.K.; Nurul Syakima, A.M.; Shiran, M.S.; Tang, Y.L.; Lin, H.P.; Hong, K. Analysis of Antarctic proteobacteria by PCR fingerprinting and screening for antimicrobial secondary metabolites. Genet. Mol. Res. 2012, 11, 1627-1641. [CrossRef] [PubMed]

10. Papa, R.; Parrilli, E.; Sannino, F.; Barbato, G.; Tutino, M.L.; Artini, M.; Selan, L. Anti-biofilm activity of the Antarctic marine bacterium Pseudoalteromonas haloplanktis TAC125. Res. Microbiol. 2013, 164, 450-456. [CrossRef] [PubMed]

11. Papaleo, M.C.; Fondi, M.; Maida, I.; Perrin, E.; Lo Giudice, A.; Michaud, L.; Mangano, S.; Bartolucci, G.; Romoli, R.; Fani, R. Sponge-associated microbial Antarctic communities exhibiting antimicrobial activity against Burkholderia cepacia complex bacteria. Biotechnol. Adv. 2012, 30, 272-293. [CrossRef] [PubMed] 
12. Papaleo, M.C.; Romoli, R.; Bartolucci, G.; Maida, I.; Perrin, E.; Fondi, M.; Orlandini, V.; Mengoni, A.; Emiliani, G.; Tutino, M.L.; et al. Bioactive volatile organic compounds from Antarctic (sponges) bacteria. N. Biotechnol. 2013, 30, 824-838. [CrossRef] [PubMed]

13. Romoli, R.; Papaleo, M.C.; de Pascale, D.; Tutino, M.L.; Michaud, L.; LoGiudice, A.; Fani, R.; Bartolucci, G. Characterization of the volatile profile of Antarctic bacteria by using solid-phase microextraction-gas chromatography-mass spectrometry. J. Mass Spectrom. 2011, 46, 1051-1059. [CrossRef] [PubMed]

14. Maida I., B.E.; Fondi, M.; Perrin, E.; Orlandini, V.; Papaleo, M.C.; Mengoni, A.; de Pascale, D.; Tutino, M.L.; Michaud, L.; Lo Giudice, A.; et al. Antimicrobial activity of Pseudoalteromonas strains isolated from the ross sea (Antarctica) vs. cystic fibrosis opportunistic pathogens. Hydrobiologia 2015. in press.

15. Romoli, R.; Papaleo, M.C.; de Pascale, D.; Tutino, M.L.; Michaud, L.; Lo Giudice, A.; Fani, R.; Bartolucci, G. GC-MS volatolomic approach to study the antimicrobial activity of the Antarctic bacterium Pseudoalteromonas sp.Tb41. Metabolomics 2013, 10, 42-51.

16. Coenye, T.; Vandamme, P. Diversity and significance of Burkholderia species occupying diverse ecological niches. Environ. Microbiol. 2003, 5, 719-729. [CrossRef] [PubMed]

17. Compant, S.; Nowak, J.; Coenye, T.; Clement, C.; Ait Barka, E. Diversity and occurrence of Burkholderia spp. In the natural environment. FEMS Microbiol. Rev. 2008, 32, 607-626. [CrossRef] [PubMed]

18. De Smet, B.; Mayo, M.; Peeters, C.; Zlosnik, J.E.; Spilker, T.; Hird, T.J.; LiPuma, J.J.; Kidd, T.J.; Kaestli, M.; Ginther, J.L.; et al. Burkholderia stagnalis sp. Nov. And Burkholderia territorii sp. Nov., two novel Burkholderia cepacia complex species from environmental and human sources. Int. J. Syst. Evol. Microbiol. 2015, 65, 2265-2271. [CrossRef] [PubMed]

19. Drevinek, P.; Mahenthiralingam, E. Burkholderia cenocepacia in cystic fibrosis: Epidemiology and molecular mechanisms of virulence. Clin. Microbiol. Infect. 2010, 16, 821-830. [CrossRef] [PubMed]

20. Ramsay, K.A.; Butler, C.A.; Paynter, S.; Ware, R.S.; Kidd, T.J.; Wainwright, C.E.; Bell, S.C. Factors influencing acquisition of Burkholderia cepacia complex organisms in patients with cystic fibrosis. J. Clin. Microbiol. 2013, 51, 3975-3980. [CrossRef] [PubMed]

21. Rose, H.; Baldwin, A.; Dowson, C.G.; Mahenthiralingam, E. Biocide susceptibility of the Burkholderia cepacia complex. J. Antimicrob. Chemother. 2009, 63, 502-510. [CrossRef] [PubMed]

22. Nash, E.F.; Thomas, A.; Whitmill, R.; Rashid, R.; Barker, B.; Rayner, R.J.; Whitehouse, J.L.; Honeybourne, D. "Cepacia syndrome" associated with Burkholderia cepacia (Genomovar I) infection in an adolescent with cystic fibrosis. Pediatr. Pulmonol. 2010, 46, 512-514. [CrossRef] [PubMed]

23. Tegos, G.P.; Haynes, M.K.; Schweizer, H.P. Dissecting novel virulent determinants in the Burkholderia cepacia complex. Virulence 2012, 3, 234-237. [CrossRef] [PubMed]

24. Sharma, A.; Jansen, R.; Nimtz, M.; Johri, B.N.; Wray, V. Rhamnolipids from the rhizosphere bacterium Pseudomonas sp. Grp(3) that reduces damping-off disease in chilli and tomato nurseries. J. Nat. Prod. 2007, 70, 941-947. [CrossRef] [PubMed]

25. De Bruyn, A.; Anteunis, M. 1H-N.m.r. study of L-rhamnose, methyl alpha-L-rhamnopyranoside, and 4-O-beta-D-galactopranosyl-L-rhamnose in deuterium oxide. Carbohydr. Res. 1976, 47, 158-163. [CrossRef]

26. Das, P.; Mukherjee, S.; Sen, R. Antimicrobial potential of a lipopeptide biosurfactant derived from a marine Bacillus circulans. J. Appl. Microbiol. 2008, 104, 1675-1684. [CrossRef] [PubMed]

27. Das, P.; Yang, X.P.; Ma, L.Z. Analysis of biosurfactants from industrially viable pseudomonas strain isolated from crude oil suggests how rhamnolipids congeners affect emulsification property and antimicrobial activity. Front. Microbiol. 2014, 5, 696. [CrossRef] [PubMed]

28. Abdel-Mawgoud, A.M.; Lepine, F.; Deziel, E. Rhamnolipids: Diversity of structures, microbial origins and roles. Appl. Microbiol. Biotechnol. 2010, 86, 1323-1336. [CrossRef] [PubMed]

29. Haba, E.; Pinazo, A.; Jauregui, O.; Espuny, M.J.; Infante, M.R.; Manresa, A. Physicochemical characterization and antimicrobial properties of rhamnolipids produced by Pseudomonas aeruginosa 47T2 NCBIM 40044. Biotechnol. Bioeng. 2003, 81, 316-322. [CrossRef] [PubMed]

30. Benincasa, M.; Abalos, A.; Oliveira, I.; Manresa, A. Chemical structure, surface properties and biological activities of the biosurfactant produced by Pseudomonas aeruginosa lBI from soapstock. Antonie van Leeuwenhoek 2004, 85, 1-8. [CrossRef] [PubMed] 
31. Haba, E.; Bouhdid, S.; Torrego-Solana, N.; Marques, A.M.; Espuny, M.J.; Garcia-Celma, M.J.; Manresa, A. Rhamnolipids as emulsifying agents for essential oil formulations: Antimicrobial effect against Candidaalbicans and methicillin-resistant Staphylococcus aureus. Int. J. Pharm. 2014, 476, 134-141. [CrossRef] [PubMed]

32. Sotirova, A.V.; Spasova, D.I.; Galabova, D.N.; Karpenko, E.; Shulga, A. Rhamnolipid-biosurfactant permeabilizing effects on gram-positive and gram-negative bacterial strains. Curr. Microbiol. 2008, 56, 639-644. [CrossRef] [PubMed]

33. Williams, J.G.; Kubelik, A.R.; Livak, K.J.; Rafalski, J.A.; Tingey, S.V. DNA polymorphisms amplified by arbitrary primers are useful as genetic markers. Nucleic Acids Res. 1990, 18, 6531-6535. [CrossRef] [PubMed]

34. Welsh, J.; McClelland, M. Fingerprinting genomes using PCR with arbitrary primers. Nucleic Acids Res. 1990, 18, 7213-7218. [CrossRef] [PubMed]

35. Mori, E.; Lio, P.; Daly, S.; Damiani, G.; Perito, B.; Fani, R. Molecular nature of RAPD markers from Haemophilus influenzae Rd genome. Res. Microbiol. 1999, 150, 83-93. [CrossRef]

36. Grifoni, A.; Bazzicalupo, M.; Di Serio, C.; Fancelli, S.; Fani, R. Identification of Azospirillum strains by restriction fragment length polymorphism of the $16 \mathrm{~s}$ rDNA and of the histidine operon. FEMS Microbiol. Lett. 1995, 127, 85-91. [CrossRef] [PubMed]

37. Sanger, F.; Nicklen, S.; Coulson, A.R. DNA sequencing with chain-terminating inhibitors. Proc. Natl. Acad. Sci. USA 1977, 74, 5463-5467. [CrossRef] [PubMed]

38. Altschul, S.F.; Madden, T.L.; Schaffer, A.A.; Zhang, J.; Zhang, Z.; Miller, W.; Lipman, D.J. Gapped BLAST and PSI-BLAST: A new generation of protein database search programs. Nucleic Acids Res. 1997, 25, 3389-3402. [CrossRef] [PubMed]

39. Thompson, J.D.; Higgins, D.G.; Gibson, T.J. Clustal W: Improving the sensitivity of progressive multiple sequence alignment through sequence weighting, position-specific gap penalties and weight matrix choice. Nucleic Acids Res. 1994, 22, 4673-4680. [CrossRef] [PubMed]

40. Saitou, N.; Nei, M. The neighbor-joining method: A new method for reconstructing phylogenetic trees. Mol. Biol. Evol. 1987, 4, 406-425. [PubMed]

41. Kimura, M. A simple method for estimating evolutionary rates of base substitutions through comparative studies of nucleotide sequences. J. Mol. Evol. 1980, 16, 111-120. [CrossRef] [PubMed]

42. Felsenstein, J. Confidence limits on phylogenies: An approach using the bootstrap. Evolution 1985, 39, 783-791. [CrossRef]

43. Bharali, P.; Saikia, J.P.; Ray, A.; Konwar, B.K. Rhamnolipid (RL) from Pseudomonas aeruginosa OBP1: A novel chemotaxis and antibacterial agent. Colloids Surf. B Biointerfaces 2013, 103, 502-509. [CrossRef] [PubMed]

44. Dobler, L.; Vilela, L.F.; Almeida, R.V.; Neves, B.C. Rhamnolipids in perspective: Gene regulatory pathways, metabolic engineering, production and technological forecasting. N. Biotechnol. 2016, 33, 123-135. [CrossRef] [PubMed]

(C) 2016 by the authors; licensee MDPI, Basel, Switzerland. This article is an open access article distributed under the terms and conditions of the Creative Commons Attribution (CC-BY) license (http://creativecommons.org/licenses/by/4.0/). 